Creative Commons User License: CC BY-NC-ND

Abstracted by: EBSCOhost, Electronic Journals Service (EJS), Google Scholar, Journal Seek, Scientific Commons,

Food and Agricultural Organization (FAO), CABI and Scopus

http://eoi.citefactor.org/10.11226/v23i4
Journal of Agricultural Extension

Vol. 23 (4) October, 2019

ISSN(e): 24086851; ISSN(Print); 1119944X

http://journal.aesonnigeria.org

http://www.ajol.info/index.php/jae

Email: editorinchief@aesonnigeria.org

\title{
Training Needs of Women Dairy Farmersin AL Saniya District, AL Qadisyah Province, Iraq
}

https://dx.doi.org/10.4314/jae.v23i4.2

\author{
Bassim Kshash H \\ Al-Qasim Green University, Agriculture College, Babylon / Iraq. \\ "correspondence: bassimhaleem@yahoo.com . Mobil; +9647811970465
}

\section{Hayat Oda K.}

Al-Qasim Green University, College of Food Science, Babylon / Iraq

Email:hayatoda97@yahoo.com. Mobile;+9647810064989

\section{Abstract}

The study examined the training needs of women dairy farmers in $A L$ Qadisyah Province, Iraq. A sample of 125 farm women was selected through random sampling. Face-to-face interviews with a structured questionnaire were used to collect data. Respondents had medium level of training needs on some dairy farming practices. Health care was the most preferred training aspect of women dairy farmers followed by feeding, clean milk production, breeding and marketing, while care and management of milking animals, disease prevention, feeding of milk animals, and preparation of milk products the most preferred training sub aspect. The study recommends that improved dairy farming practices should be diffuse through training and women dairy farmers should be encourage to apply the training in their dairy farms.

Keywords: Dairy cow, Livestock farmers, Milk production, Training need

\section{Introduction}

Dairy Cows contribute nearly $85 \%$ of the milk production in the whole world (Gebeyew et al., 2016). In Asia over $80 \%$ of the milk is produced by small-scale farmers (FAO, 2014a). Smallholder dairy farming system constitutes an important source of livelihoods to the majority of mixed crop-livestock farmers involved in agricultural production.

In most of Iraqi rural communities mixed crop and livestock production system is widespread, which includes raising small numbers of livestock. Livestock production has been traditionally practiced in most parts of Iraq; and it mainly includes sheep, cow, goats, buffalo and camel. There are 7,722,375 heads of sheep, 2,552,113 heads of cow, $1,474,845$ heads of goats, 285,437 heads of water buffalo, and 58,293 heads of camel in Iraq. Cow represents $21.10 \%$ of livestock in Iraq. ALQadisiyah province ranked 10th in terms of cow population $(151,094)(C S O, 2011)$. Cows are very important in traditional mixed crop livestock production systems.

Milk production of cow in Iraq is estimated at 923 liters per lactation period of 280 days, the productivity was 3.6 liters/day, and it is accounting for less than $40 \%$ of other countries (MOP, 2013). This productivity was very low compared with Saudi 
Creative Commons User License: CC BY-NC-ND

Abstracted by: EBSCOhost, Electronic Journals Service (EJS), Google Scholar, Journal Seek, Scientific Commons,

Food and Agricultural Organization (FAO), CABI and Scopus

http://eoi.citefactor.org/10.11226/v23i4
Journal of Agricultural Extension

Vol. 23 (4) October, 2019

ISSN(e): 24086851; ISSN(Print); 1119944X

http://journal.aesonnigeria.org

http://www.ajol.info/index.php/iae

Email: editorinchief@aesonnigeria.org

Arabia (10.133), United Kingdom (7.271), Germany (6.877), Jordan (6.521), and Kuwait (6.448) liters per cow, (FAO, 2012), in Turkey (16.18) kg/cow, (Cukur, 2016). One of the major reasons of low productivity could be due to traditional dairy farming practices by farmers.

Small-scale livestock farmers, sometimes referred to as smallholder farmers, are mainly categorized by the livestock numbers (Ogunkoya, 2014). Some authors consider small-scale to be from 2 to 15 animals, others consider it to be up to 20 milking animals plus replacement heifers, or even up to 50 cattle (FAO, 2014b). Dairy cows in small holders contribute to improve the welfare of farm households, It generates income, provides a highly nutritious food for people, creates employment opportunities in the society (Nga et al., 2012).

Women have been involved in animal production under small holder farming system to enhance the family income as well as to meet household food needs (Batool et al., 2014). The responsibility of all sorts of activities involved in animal husbandry occupation is shouldered by women farmers (Naik et al., 2014). It is widely accepted that most of the critical roles related to livestock farming are played by the women (Arshad et al. 2013; Andaleeb et al. 2017; Mthi et al. 2018). Rural women play a major role in dairy production systems: they often feed the animals; milk them; clean the animals and their stall; compost manure and are often responsible for breeding, health and the sale of milk. (FAO, 2015)

Dairy farming is major occupation of rural women in Iraqi village. The ability of the women dairy farmers to increase productivity and generate more income from dairying depends on the effective use and application of improved dairy farming practices. Dairy development strategy at smallholder level requires some change in knowledge and management skills, which calls for training on improved dairy farming practices (Lemma et al.2018).

Some recent studies; Prajapati et al. (2019), Raina et al. (2017), Patel et al.(2016), Roy (2015), Tyapo et al. (2015), Kanwat and Singh(2014), Kathiriya et al.(2014), Kavithaa and Rajkumar(2014), Jadav et al.(2014), Jacop and George(2013a), Kale et al.(2013), Luqman et al.(2013), Patel et al. (2012), Rajput et al.( 2012), Saiyad and Badhe(2012), have been conducted in many countries aim at assessing training needs of women dairy farmers. These studies indicated that the most preferred training needs of women dairy farmers in aspects and sub-aspects of dairy farming were; feeding and fodder production, breeding, balanced diet, clean milk production, housing, marketing, finance, health care, common diseases of milking animals and disease control, calf rearing and milk processing, milking hygiene practices, vaccination schedule, care of cow at time of calving and after calving.

To make training more effective, training needs should determine prior to commencement of training programs, so the subject matter of training can be established on the basis of trainees' needs. Therefore, we need to study the training needs of women dairy farmers in Iraq in order to promote their skills, expertise and enhance milk production and productivity, to make dairying a successful enterprise, especially, as similar studies is limited in Iraq. Therefore, this study assessed training needs of women dairy farmers. The findings presented in this paper provide information on training needs of women dairy farmers in some 
Creative Commons User License: CC BY-NC-ND

Abstracted by: EBSCOhost, Electronic Journals Service (EJS), Google Scholar, Journal Seek, Scientific Commons,

Food and Agricultural Organization (FAO), CABI and Scopus

http://eoi.citefactor.org/10.11226/v23i4
Journal of Agricultural Extension

Vol. 23 (4) October, 2019

ISSN(e): 24086851; ISSN(Print); 1119944X

http://journal.aesonnigeria.org

http://www.ajol.info/index.php/jae

Email: editorinchief@aesonnigeria.org

dairy farming practices that may be useful for extension agencies to develop suitable training programs for dairy farm women.

\section{Methodology}

The study was conducted in AL-Saniyah district, AL-Qadisiyah province lies between 31.17 to 32.24 North latitude and 44.24 to 45.49 East longitudes. The district covers a total of 210 square kilometres of landmass constitute $2 \%$ of province area, and population stands at 55,656 constitute $4.22 \%$ of province population, about $81 \%$ of them lives in rural area (SDQ, 2016). Agriculture is the major source of income for a great number of people of AL-Saniya district.

The major farming activity in the study area was crop-livestock production. Large percent of district area is under cultivation for crop production. Some of the most widely cultivated crops are vegetables, wheat, barley, alfalfa, clover, and fruits, especially Figs, in addition to the existence of palm groves. The district is famous for its cattle breeding. There are 9,373 heads of sheep, 2,668 heads of cow, 1,347 heads of water buffalo, and 1,414 heads of goats in the district. Cow represents $2.8 \%$ of cows in the province (CSO, 2011). Cows are the most source of milk. There is Al-Qadisiyah dairy factory, the 2nd biggest dairy factory in Iraq which was established in 1981.

Study population consisted of 387 women farmers practicing dairy in the district, from where 125 were selected at random. The instrument used was a 2 part questionnaire. The first included socio-economic characteristics: age, number of dairy cows, and years of experience in dairy farming. The second part included 5 aspects of dairy farming practices with 47 sub-aspects: health care (13 subaspects), feeding (11), clean milk production (7), breeding (13) and marketing (3). Content validity of the questionnaire was established by a panel of experts in fields of agricultural extension and cows or milk production. A pilot study was conducted on 12 women outside the sample to establish reliability of the instrument, and a Cronbach's alpha (a reliability coefficient) of 0.91 was established, indicating the instrument used was reliable and valid.

To determine training needs, schedule was developed. These were determined with the help of 4 Likert-like scale; very highly needed (VHN) (4), highly needed (HN) (3), moderately needed (MN) (2) and slightly needed (SN) (1). Perceived training needs of individual practices were determined after taking in to consideration its respective obtained score, each respondent was given a score ranging from (47 to 188). Based on mean (M) \pm standard deviation (SD), respondents, and the 5 main aspects were assigned to categories as follows: low training needs (below M-SD), medium $(\mathrm{M} \pm \mathrm{SD}$ ), and high (above $\mathrm{M}+\mathrm{SD}$ ). Each aspect was given a score ranging from (1 to 4). The 47 sup-aspects were categorized based on weighted arithmetic mean (WM) for level of training in it, into: low (1-1.9), medium (2-2.9) and high (3-4).

Face to face interviews were used and data collected by researcher's visits to respondents between $10^{\text {th }}$ and $22^{\text {nd }}$ August, 2018. Data were analyzed using 
Creative Commons User License: CC BY-NC-ND

Abstracted by: EBSCOhost, Electronic Journals Service (EJS), Google Scholar, Journal Seek, Scientific Commons,

Food and Agricultural Organization (FAO), CABI and Scopus

http://eoi.citefactor.org/10.11226/v23i4
Journal of Agricultural Extension

Vol. 23 (4) October, 2019

ISSN(e): 24086851; ISSN(Print); 1119944X

http://journal.aesonnigeria.org

http://www.ajol.info/index.php/jae

Email: editorinchief@aesonnigeria.org

frequency, percentage, mean(M), standard deviation (SD) and weighted arithmetic mean (WM).

\section{Results and Discussion}

\section{Characteristics of Farm Women}

Table I shows the selected characters of the respondents. The results indicate that respondents were divided depending on their age to $(20,30.4,36,13.6 \%)$ within (17- 27, 28-38, 39-49, 50-60) years, respectively, the average age was (37.7) years. It indicates that the majority of rural women in the research area are young, still strong and capable of undertaking rigorous activities in dairy farming management, they are likely to be less cautious of undertaking risks to improve their dairy farm enterprise.

By number of dairy cows, they owned, results show that $35.2 \%, 45.6 \%$ and, $15.2 \%$ owned between 1-3, 4- 6, 7- 9 cows, respectively while only $4.0 \%$ owned between 10 and 12 cows. The average cow numbers owned was 4.6 which strongly suggest that most of women farmers in the locality operated on a small scale dairy farm.

On years of experience in dairy farming, they ranged from 5 to 48 years, and the mean years of experience in dairy farming was 23.8 years. This means that women in the study area participate in dairy farm activities from $t$ an early age.

Table 1: Characteristics of dairy farm women

\begin{tabular}{lcccc}
\hline Characteristic & Category & $\%$ & Mean & S.D. \\
\hline Age (years) & $17-27$ & 20.0 & & \\
& $28-38$ & 30.4 & 37.7 & 13.8 \\
Number of dairy cow owned & $39-49$ & 36.0 & & \\
& $50-60$ & 13.6 & & \\
Experience's years & $1-3$ & 35.2 & & \\
& $4-6$ & 45.6 & 4.6 & 1.7 \\
& $7-9$ & 15.2 & & \\
& $10-12$ & 4.00 & & \\
& $5-15$ & 19.2 & & \\
& $16-26$ & 44.0 & 23.8 & 12.4 \\
& $27-37$ & 28.8 & & \\
\hline
\end{tabular}

\section{Overall Training Needs}

Training needs score of rural women ranged from (47-188), with a mean of 123 and standard deviation of 25 . Based on mean $(\mathrm{M}) \pm$ standard deviation (SD), respondents were classified into three categories, which has been presented in Table 2. 
Creative Commons User License: CC BY-NC-ND

Abstracted by: EBSCOhost, Electronic Journals Service (EJS), Google Scholar, Journal Seek, Scientific Commons,

Food and Agricultural Organization (FAO), CABI and Scopus
Journal of Agricultural Extension

Vol. 23 (4) October, 2019

ISSN(e): 24086851; ISSN(Print); 1119944X

http://journal.aesonnigeria.org

http://www.ajol.info/index.php/iae

Email: editorinchief@aesonnigeria.org

For the first category, the mean need score for training is less than the upper limit of training need by 33 score, this shows the weakness need for training among respondents in this category. As regard to second category, the difference between the mean and the upper limit of training need has reached 19 score, which represents a medium need for training.

For the third category, respondents showed the less difference between mean and the upper limit of training need, that reached 13 score. This shows the highly need for training among respondents in this category. The mean needs for training for all respondents were (123) which are within medium Category.

Table 2: Training needs.

\begin{tabular}{lcl}
\hline Training needs category $^{\mathrm{a}}$ & Mean & SD \\
\hline Low $(<98)$ & 64.7 & 22.3 \\
Medium (98-148) & 129.8 & 37.6 \\
High $(>148)$ & 174.5 & 8.7 \\
\hline Total $(47-188)$ & 123.0 & 25.0
\end{tabular}

${ }^{a}$ According to total Mean and SD, categories were determined as; low

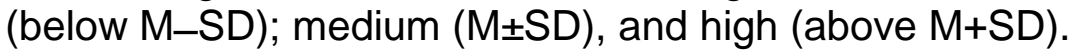

\section{Training Needs on Some Aspects of Dairy Farming Practices}

With respect to overall preference of training need of women dairy farmers Table 3 reveals that health care is the most preferred training aspect of women dairy farmers $(\bar{x}=3.4)$ followed by feeding $(\bar{x}=3.1)$, clean milk production $(\bar{x}=2.8)$, breeding $(\bar{x}=2.2)$ and marketing $(\bar{x}=1.6)$. The overall training need index of improved dairy farming practices were $(\bar{x}=2.62)$. This means that training needs in aspects of health care and feeding were high, medium in clean milk production, breeding and was low in marketing aspect. The results were similar with findings of Roy (2015) and Kale et al., (2013).

With regard to health care, the highly training needs of respondents is due to fact that parasites and various diseases in animals generally cause greater economic losses to dairy farm breeders by mortality and morbidity, which influence the quality and quantity of milk. Animal health care improved practices keep animals healthy and improve quantity as well as quality of milk production and reduce expenditure on animal health. FAO (2014b) revealed that in small-scale units of dairy farm, diseases often rank as the most important constraints on production, so, improved animal health care is an essential issue for small-scale farm development. Therefore, women dairy farmers in the district felt the high need for training in health care.

Feeding is the most important factor in successful animal care. Dairy cow can realize its production potential when it is fed well by given appropriate foods. Annah et 
Creative Commons User License: CC BY-NC-ND

Abstracted by: EBSCOhost, Electronic Journals Service (EJS), Google Scholar, Journal Seek, Scientific Commons,

Food and Agricultural Organization (FAO), CABI and Scopus
Journal of Agricultural Extension

Vol. 23 (4) October, 2019

ISSN(e): 24086851; ISSN(Print); 1119944X

http://journal.aesonnigeria.org

http://www.ajol.info/index.php/iae

Email: editorinchief@aesonnigeria.org

al.(2018) indicated that poor nutrition results in low production and reproductive performance slow growth rate, loss of body condition and increased susceptibility to diseases and parasites, while Shyam et al.(2016) see that balance feed and its composition and time of feeding in dairy cows was very important factor to get optimum production .So, the most respondents felt high training needs on feeding to gain knowledge, skills, and improved practices to be able to feed their cows optimally.

Clean milk means the raw milk that has been produced in the udder of healthy dairy animals, handled under hygienic conditions and contains only allowed quantity of pathogens and chemicals (Jacop and George, 2013b). Women dairy farmers are interested in clean milk production practices because milk is the main product from a dairy enterprise, and women must therefore aim at maximizing on milk output from their dairy cows, at the same time must ensure that milk is produced in clean and hygienic conditions so that it is fit for human consumption.

In case of breeding, the less training needs may be due to the fact that many of these practices are done by men because it requires greater strength and contact with people from outside the village. In the same context, Jadav et al.(2014) sees that since the major farm operations of breeding, require outside contact, the involvement of women farmers was less and this might be the reason for the women farmers' preference of these major farm operations as the least preferred areas of training.

Marketing was the aspect in which most of respondents felt low level of training needs. Similar results were also reported by Dhaka et al.(2017). This result may be due to milk marketing system, common in Iraq, that is done through intermediaries who collect milk from homes and then market it to the dairy factory, which means decline of women's participation in marketing activities. Yasmin and Ikemoto (2015), Ogdand and Hembade (2014) also reiterated this.

Table 3: Training need for training on aspect of dairy farming.

\begin{tabular}{lll}
\hline Aspect & $\bar{x}$ & SD \\
\hline Health care & 3.4 & 0.47 \\
Feeding & 3.1 & 0.54 \\
Clean milk production & 2.8 & 0.89 \\
Breeding & 2.2 & 0.93 \\
Marketing & 1.6 \\
\hline
\end{tabular}


Creative Commons User License: CC BY-NC-ND

Abstracted by: EBSCOhost, Electronic Journals Service (EJS), Google Scholar, Journal Seek, Scientific Commons,

Food and Agricultural Organization (FAO), CABI and Scopus
Journal of Agricultural Extension

Vol. 23 (4) October, 2019

ISSN(e): 24086851; ISSN(Print); 1119944X

http://journal.aesonnigeria.org

http://www.ajol.info/index.php/jae

Email: editorinchief@aesonnigeria.org

\section{Training Needs on Sub-Aspects of Dairy Farming Practices}

Regarding training needs on sub-aspects of animal health care practices; result in Table 4 reveals that women dairy farmers expressed high training needs in all subaspects. The most important was care and management of milking animals, disease prevention $(\bar{x}=3.8)$ followed by symptoms of common diseases, information on infectious diseases $(\bar{x}=3.7)$ care and management of sick animals $(\bar{x}=3.6)$, sterility treatments $(\bar{x}=3.5)$, precaution against parasitic diseases $(\bar{x}=3.4)$. Similar findings were reported by Tyabo et al.(2015); Kavithaa and Rajkumar (2014); and Patel et al.(2012).

Among the various sub-aspects of feeding practices, feeding of milking animals was the most important and ranked first by the respondents for the purpose of training $(\bar{x}=3.7)$ followed by importance of feeding mineral mixture $(\bar{x}=3.6)$, feeding of pregnant animals $(\bar{x}=3.5)$, feeding of new born calves $(\bar{x}=3.3)$ and advantage of compounded $(\bar{x}=3.2)$. These results are in consonance with the findings of Subash et al.(2015).

Under clean milk production aspect, women dairy farmers considered preparation of milk products as the most important training needs $(\bar{x}=3.7)$, which means that women dairy farmers want to know more about preparation of milk products because that returns from manufacturing and marketing of dairy products are greater than the return from marketing raw milk. This was followed by knowledge of zoonotic disease that spread through infected milk $(\bar{x}=3.5)$.

Training need of women dairy farmers with respect to breeding practices revealed that breeding program ranked first $(\bar{x}=3.2)$ followed by rearing the calves $(\bar{x}=3.1)$, repeat breeding management and reproductive efficiency of dairy animal $(\bar{x}=3.0)$. About the training need with respect to marketing, marketing of products was in first rank $(\bar{x}=1.9)$ followed by milk marketing $(\bar{x}=1.8)$. 
Creative Commons User License: CC BY-NC-ND

Journal of Agricultural Extension

Abstracted by: EBSCOhost, Electronic Journals Service (EJS), Vol. 23 (4) October, 2019

Google Scholar, Journal Seek, Scientific Commons,

ISSN(e): 24086851; ISSN(Print); 1119944X

Food and Agricultural Organization (FAO), CABI and Scopus

http://journal.aesonnigeria.org

http://www.ajol.info/index.php/jae

http://eoi.citefactor.org/10.11226/v23i4

Email: editorinchief@aesonnigeria.org

Table 4: Training needs in sub aspects of dairy farming

\begin{tabular}{|c|c|c|}
\hline Aspects & Sup aspects & $\bar{x}$ \\
\hline \multirow[t]{13}{*}{ Health care } & Care and management of milking animals & 3.8 \\
\hline & Disease Prevention & 3.8 \\
\hline & Symptoms of common diseases & 3.7 \\
\hline & Information on infectious diseases & 3.7 \\
\hline & Care and management of sick animals & 3.6 \\
\hline & Sterility treatments & 3.5 \\
\hline & Precaution against parasitic diseases & 3.4 \\
\hline & Care and management of new born calves & 3.3 \\
\hline & First aid measures to be taken during emergency & 3.2 \\
\hline & Deworming schedule and procedures & 3.2 \\
\hline & Care and management of pregnant animals at the time of parturition & 3.1 \\
\hline & Treatment against contagious diseases & 3.0 \\
\hline & Vaccination schedule & 3.0 \\
\hline \multirow[t]{11}{*}{ Feeding } & Feeding of milk animals & 3.7 \\
\hline & Importance of feeding mineral mixture & 3.6 \\
\hline & Feeding of pregnant animals & 3.5 \\
\hline & Feeding of new born calves & 3.3 \\
\hline & Advantage of compounded & 3.2 \\
\hline & Preparation of balanced ration for their animals at a cheaper rate & 3.0 \\
\hline & Conservation of fodder crops & 2.9 \\
\hline & Feeding of dry animals & 2.8 \\
\hline & Time and frequency of feeding & 2.8 \\
\hline & Fodder cultivation & 2.7 \\
\hline & Silage making & 2.6 \\
\hline Clean milk & Preparation of milk products & 3.7 \\
\hline \multirow[t]{6}{*}{ production } & Knowledge of zoonotic disease that spread through infected milk & 3.5 \\
\hline & Type of milking & 2.9 \\
\hline & Hygienic method of clean milk production & 2.7 \\
\hline & Value addition of milk & 2.5 \\
\hline & Storage of excess milk & 2.4 \\
\hline & Preservation of milk and milk products & 1.9 \\
\hline \multirow[t]{13}{*}{ Breeding } & Breeding program & 3.2 \\
\hline & Rearing the calves & 3.1 \\
\hline & Repeat breeding management & 3.0 \\
\hline & Reproductive efficiency of dairy animal & 3.0 \\
\hline & Selection of breeds & 2.3 \\
\hline & Knowledge of high yielding breed & 2.3 \\
\hline & Maintenance of records on breeding & 2.2 \\
\hline & Detection of heat symptoms & 2.1 \\
\hline & Pregnancy diagnosis & 2.1 \\
\hline & Time of post-partum insemination & 2.0 \\
\hline & Infertility problems and Reproductive disorder & 1.4 \\
\hline & Selection of adult animal and dairy heifer & 1.3 \\
\hline & Time of artificial insemination & 1.1 \\
\hline \multirow[t]{3}{*}{ Marketing } & Marketing of products & 1.9 \\
\hline & Milk marketing & 1.8 \\
\hline & Marketing of livestock & 1.1 \\
\hline
\end{tabular}


Creative Commons User License: CC BY-NC-ND

Abstracted by: EBSCOhost, Electronic Journals Service (EJS), Google Scholar, Journal Seek, Scientific Commons,

Food and Agricultural Organization (FAO), CABI and Scopus
Journal of Agricultural Extension

Vol. 23 (4) October, 2019

ISSN(e): 24086851; ISSN(Print); 1119944X

http://journal.aesonnigeria.org

http://www.ajol.info/index.php/jae

Email: editorinchief@aesonnigeria.org

\section{Conclusion and Recommendations}

Women dairy farmers had medium training needs regarding improved dairy farm practices. They expressed high training needs in health care, and feeding. With regard to health care, they had high level of training needs with farm practices like care and management of milking animals, disease prevention, symptoms of common diseases, information on infectious diseases, care and management of sick animals. Training needs were also high for feeding, practices, especially for feeding of milking animals and importance of feeding mineral mixture, clean milk production and preparation of milk products.

To increase milk production and productivity in small scale dairy farms, improved and scientific dairy farming practices should be made available to the women farmers. Training course should be conducted for women dairy farmers where respondents high training needs.

\section{References}

Andaleeb, N., M. Khan and S. Shah.(2017). Factors affecting women participation in livestock farming in District Mardan, Khyber Pakhtunkhwa, Pakistan. Sarhad Journal of Agriculture, 33(2): 288-292. DOI |

http://dx.doi.org/10.17582/journal.sja/2017/33.2.288.292

Annah, S., T. Zindove, and M. Chimonyo. (2018). Perceptions of factors affecting milk quality and safety among large- and small-scale dairy farmers in Zimbabwe. Journal of Food Quality, vol. 2018, Article ID 5345874, 7 pages. https://doi.org/10.1155/2018/5345874.

Arshad, S., S. Muhammad and I. Ashraf. ( 2013). Women's participation in livestock farming activities. The Journal of Animal \& Plant Sciences, 23(1): 304-308. http://www.thejaps.org.pk/docs/v-23-1/46.pdf

Batool, Z., H. Warriach, M. Ishaq, S. Latif, M. Rashid, A. Bhatti, N. Murtaza, S. Arif and P. Wynn.(2014). Participation of women in dairy farm practices under small holder production system in Punjab, Pakistan. The Journal of Animal and Plant Sciences, 24(4): 1263-1265. http://www.thejaps.org.pk/Volume/2014/24-4/index.php.

CSO (Central Statistical Organization Iraq). (2011). Agricultural Statistical Atlas roadmap for Agricultural Development, Iraq, Baghdad.

Cukur, T. (2016). Factors effecting dairy farmers' application of agricultural innovations: a case study from Mugla Province. Turkish Journal of Agriculture - Food Science and Technology, 4(7): 611-617. DOI: https://doi.org/10.24925/turjaf.v4i7.611-617.713

Dhaka, B., R. Bairwa, N. Meena, G. Meena, K. Chayal and B. Nagar. (2017). Training needs assessment of women farmers on livestock production management in Bundi District of Rajasthan, India. International Journal of Current Microbiology and Applied Sciences, 6(6): 796- 803. DOI: https://doi.org/10.20546/ijcmas.2017.606.093. 
Creative Commons User License: CC BY-NC-ND

Abstracted by: EBSCOhost, Electronic Journals Service (EJS), Google Scholar, Journal Seek, Scientific Commons,

Food and Agricultural Organization (FAO), CABI and Scopus

http://eoi.citefactor.org/10.11226/v23i4
Journal of Agricultural Extension

Vol. 23 (4) October, 2019

ISSN(e): 24086851; ISSN(Print); 1119944X

http://journal.aesonnigeria.org

http://www.ajol.info/index.php/iae

Email: editorinchief@aesonnigeria.org

FAO(Food and Agriculture Organization of the United Nations.). (2015). Empowering women in Afghanistan: Reducing gender gaps through integrated dairy schemes. Rome. http://www.fao.org/3/a-i4585e.pdf

Food and Agriculture Organization of the United Nations (FAO ).(2014a). Dairy Asia:

Towards sustainability. Rome. http://www.fao.org/3/a-i3985e.pdf

Food and Agriculture Organization of the United Nations (FAO ). (2014b). Impact of mastitis in small scale dairy production systems, animal Production and health. Working Paper, no.13.. Rome. www.fao.org/3/a-i3377e.pdf.

Food and Agriculture Organization of the United Nations (FAO ). (2012). FAO statistical yearbook 2012. Rome. http://reliefweb.int/sites/reliefweb.int/files/resources/i2490e.pdf

Gebeyew, K., S. Amakelew, M. Eshetu and G. Animut. (2016). Production, processing and handling of cow milk in Dawa Chefa District, Amhara Region, Ethiopia. Journal of Veterinary Science and Technology, 7(1):286-294. DOI: 10.4172/2157-7579.1000286

Jacop, S. and George, A. (2013a). Assessing the training need of dairy farmers on scientific cattle management practices. International Journal Of Scientific Research, 2(7):946947.

Jacop, S. and George, A.(2013b). Analysis of the clean milk production practices of dairy farmers of Kerala. Indian Journal of Applied Research, 3(7):604-606. DOI:10.15373/2249555X

Jadav, S., V. Rani, S. Mudgal and H. Dhamsaniya.(2014). women empowerment through training in dairy farming. Asian Journal of Dairy and Food Research, 33(2):147-153. DOI: $10.5958 / 0976-0563.2014 .00592 .2$

Kale, R., V. Tekale and R. Dhere. (2013). Training need of the farm women in dairy farming. Agriculture Update, 8(4): 583-585. http://www.researchjournal.co.in/online/AU/AU-8-42013.htm

Kanwat, M. and P. Singh. (2014).Technological needs of farm women in dairy farming: a case of Udaipur District, Rajasthan. Indian Research Journal of Extension Education, 14(3): 28-30. http://www.seea.org.in/vol14-3-index.html

Kathiriya J., D. Saradava, D. Sanepara and B. Kabaria. (2014). Training needs of dairy farming women and constraints faced by rural women: a case study of Gujarat. International Journal of Agricultural Science and Veterinary Medicine, 2(2):46-50. https://www.ijasvm.com/previousissue. php?year=2014\&issue $=2$

Kavithaa, N. and V. Rajkumar. (2014).Training needs of rural women on improved dairy farming practices. International Journal of Science, Environment and Technology, 3(6):2046- 2050. http://www.ijset.net/index issue.php?iid=35

Lemma, H., A. Mengistu, T. Kuma, and B. Kuma.(2018).Improving milk safety at farm-level in an intensive dairy production system: relevance to smallholder dairy producers .Food Quality and Safety,2(3):135-143, https://doi.org/10.1093/fqsafe/fyy009

Luqman, M., S. Babar, A. Izhar and S. Umair. (2013). Training need assessment of rural women in livestock management - case of southern Punjab, Pakistan. Journal of Agricultural Research, 51(1):99-108. http://apply.jar.punjab.gov.pk/issues/current_issues/72

Ministry Of Planning (MOP). (2013). National development plan 2013- 2017, Baghdad. 
Creative Commons User License: CC BY-NC-ND

Abstracted by: EBSCOhost, Electronic Journals Service (EJS), Google Scholar, Journal Seek, Scientific Commons,

Food and Agricultural Organization (FAO), CABI and Scopus

http://eoi.citefactor.org/10.11226/v23i4
Journal of Agricultural Extension

Vol. 23 (4) October, 2019

ISSN(e): 24086851; ISSN(Print); 1119944X

http://journal.aesonnigeria.org

http://www.ajol.info/index.php/jae

Email: editorinchief@aesonnigeria.org

Mthi, S., N. Nyangiwe, R. Menhas, A. Mushunje and I. Ighodaro.( 2018). Women's participation in livestock activities under small-scale farming system in the Eastern Cape Province, South Africa. Applied Animal Husbandry \& Rural Development , 11(1):14-21. https://www.sasas.co.za/aahrd-years/2018/

Naik, R., M. Prajapati and N. Patel.(2014). Involvement of farm women in decision making pattern for dairy farming. Unique Journal of Medical and Dental Sciences, 2(04),6163. http://ujconline.net/wp-content/uploads/2013/09/16-UJMDS-14163-Rs.pdf

Nga, B., T. Cuong , T. Ha and P. Lebailly. (2012). Milk production and marketing in small dairy holders in the Northern area of Vietnam: a case study in Phu Dong, Vietnam. Vietnam's socio-economic development: a social science review, 7:57-69. http://hdl.handle.net/2268/148140

Ogdand, G. and A. Hembade. (2014). Studies on the participation of women in decisionmaking about dairy occupation in Parbhani district of Maharashtra state. International Journal of Current Research and Academic Review, 2(8):367-372. http://www.ijcrar.com/vol-2-8/G.G.ogdand\%20and\%20A.S. Hembade.pdf

Ogunkoya, F.(2014). Socio-economic factors that affect livestock numbers: a case study of smallholder cattle and sheep farmers in the Free State province of South Africa, M.SC., University of South Africa.

Patel, R., K. Patel and R. Prajapati. (2016). Training needs assessment of dairy farm women in dairy practices. International Journal of Agriculture Sciences, 8(13):1225-1227. http://www.bioinfopublication.org/jouarchive.php?opt=\&jouid=BPJ0000217

Patel, R., T. Patel and M. Prajapati. (2012). Training need of dairy farm women in dairy farming practices. AGRES - An International e-Journal, 1(4):463-468.

http://arkgroup.arkgroup.co.in/Article.aspx?ID=JOUR75

Prajapati, V., P. Sharma, S. Undhad, N. Jadav and A. Parmar.(2019). Training needs of dairy farm women regarding scientific animal husbandry practices in Rajkot District of Gujarat. International Journal of Current Microbiology and Applied Sciences, 8(03): 263-268. doi: https://doi.org/10.20546/ijcmas.2019.803.033

Raina, V., N. Sharma, S. Khajuria, K. Kumar, S. Choudhary, Z. Syed and K. Hussain.(2017). Training needs of dairy farmers. International Journal of Agriculture, Environment and Biotechnology, 10(2):245-251. DOI: 10.5958/2230-732X.2017.00029.8

Rajput, B., C. Sahu, K. Kamala and K. Ram. (2012). Perceived training needs of dairy farmers regarding improved dairy farming practices and its relation with their socioeconomic traits in Bundelkhand region. Indian Journal of Dairy Science, 65(4):342347. http://epubs.icar.org.in/ejournal/index.php/IJDS/issue/view/742

Roy, R.. (2015). Training needs of pig farmers in Darjeeling Hills. Indian Journal of Hill Farming, 28(2):133-136. http://epubs.icar.org.in/ejournal/index.php/lJHF/issue/view/1415

Saiyad, A. and K. Badhe. (2012). Training needs of rural women regarding animal husbandry. Agriculture Update, 7(1\&2):30-32. http://www.researchjournal.co.in/online/AU/AU\%207(1\&2)/7 A-30-32.pdf

SDQ (Statistics Directorate of Al- Qadisiyah) ,2016 : population estimates of AL-Qadisiyah province for the year 2015. unpublished data. 
Creative Commons User License: CC BY-NC-ND

Abstracted by: EBSCOhost, Electronic Journals Service (EJS), Google Scholar, Journal Seek, Scientific Commons,

Food and Agricultural Organization (FAO), CABI and Scopus

http://eoi.citefactor.org/10.11226/v23i4
Journal of Agricultural Extension

Vol. 23 (4) October, 2019

ISSN(e): 24086851; ISSN(Print); 1119944X

http://journal.aesonnigeria.org

http://www.ajol.info/index.php/jae

Email: editorinchief@aesonnigeria.org

Shyam, J., H. Tripathi and B. Balaraju. (2016). Training needs of rural youths in various livestock production practices. Indian Journal of Social Research, 57(4):487-491. http://www.academic-and-law-serials.com/component/content/article.html?id=810

Subash, S., J. Gupta and G. Babu. (2015). Information needs assessment and prioritization of dairy farmers. Journal of Krishi Vigyan, 4(1):51-55.

DOI: $10.5958 / 2349-4433.2015 .00059 .8$

Tyabo, S., M. Ibrahim, A. Ndanista, S. Umar and H. Tsado. (2015). Training needs of rural women on livestock management in Niger state, Nigeria. Nigerian Journal of Agriculture, Food and Environment, 11(1):160-164. http://www.njafe.org/njafe2015Vol11 number1.html

Yasmin, S. and Y. Ikemoto. (2015). Women's empowerment through small-scale dairy farming in selected areas of Bangladesh. American International Journal of Social Science, 4(5): 21-33.

http://www.aijssnet.com/journals/Vol_4_No_5_October_2015/3.pdf. 